\title{
RATIONALIZING INFANTICIDE: A MEDICO-LEGAL ASSESSMENT OF THE CRIMINAL CODE'S CHILD HOMICIDE OFFENCE
}

\author{
SANJEEV ANAND*
}

This article involves a discussion of the proper scope and interpretation of the Criminal Code provisions relating to the offence of infanticide. A review of the legislative history indicates that the biological rationale for the offence did not appear to have been scientifically established. Thus, despite the wording of the provision, the law of infanticide developed not from medical science, but instead as a way of dealing with unsatisfactory outcomes of homicide litigation directed at new mothers. In recent years, the medical rationale for infanticide has become less accepted and the trend has been to charge more mothers accused of killing their newborns with murder. This may be attributed, in part, because the conditions that created a sympathetic response to young women facing unwanted children in the past no longer exist. Nevertheless, it is asserted that the stress of child rearing should serve to reduce the culpability of some individuals who kill their children. Consequently, the author recommends a repeal of the current infanticide provisions, to be replaced by a more generally applicable defence of diminished responsibility applicable to not just biological mothers, but fathers and adoptive parents as well.
Cet article comprend une discussion sur la portée et l'interprétation correctes des dispositions du Code criminel relatives à l'infanticide. L'examen de l'historique législatif révèle que les raisons biologiques de ce délit ne semblent pas avoir été établies de manière scientifique. Ainsi, malgré la formulation de la disposition, la loi sur l'infanticide a été développée non pas à partir de la science médicale, mais plutôt comme moyen d'aborder les conclusions insatisfaisantes d'un procès pour homicide dirigé contre de nouvelles mères. Au cours des dernières années, le raisonnement médical au sujet de l'infanticide est de moins en moins accepté et la tendance est plutôt d'inculper de meurtre les mères accusées de tuer leur nouveau-né. Cette tendance peut être attribuée, en partie, au fait que les conditions, qui suscitaient une réaction sympathique pour les jeunes femmes faisant face autrefois à des enfants non désirés, n'existent plus. Néanmoins, il fait faire valoir le fait que le stress lié à l'éducation des enfants devrait aider à réduire la culpabilité de certaines personnes qui tuent leurs enfants. Par conséquent, l'auteur recommande d'abroger les dispositions actuelles sur l'infanticide et de les remplacer par une défense plus générale de responsabilité atténuée applicable non seulement aux mères biologiques, mais aussi aux pères et aux parents adoptifs.

\section{TABLE OF CONTENTS}

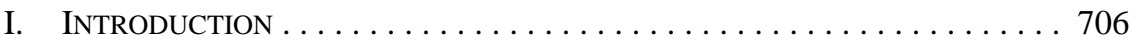

II. The CRiminal Code Offence/Defence of Infanticide . . . . . . . 707

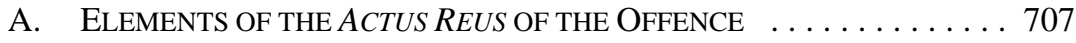

B. Resolving Ambiguities ConCERning THE

ACTUS REUS OF THE OFFENCE $\ldots \ldots \ldots \ldots \ldots \ldots \ldots \ldots \ldots \ldots$

C. THE MENS REA OF THE OfFENCE $\ldots \ldots \ldots \ldots \ldots \ldots \ldots \ldots \ldots \ldots$

D. Settling the Mens ReA DebAte $\ldots \ldots \ldots \ldots \ldots \ldots \ldots \ldots \ldots$

E. The Infanticide Defence . . . . . . . . . . . . . . . . . . . 718

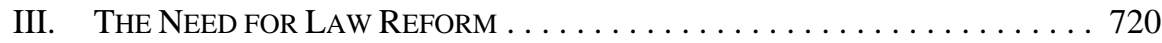

A. AsSESSING THE BIOLOGICAL BASIS FOR THE INFANTICIDE OFFENCE/DEFENCE . . . . . . . . . . . . 720

Professor, Faculty of Law, University of Alberta. The author thanks Professor Kent Roach for his helpful comments on an earlier draft of this article. The author also expresses gratitude to Nicholette Anand for her invaluable editing assistance as well as Priya, Seraphina, and Arun Anand for their patience during the writing process. 
B. LAW REFORM IMPLICATIONS . . . . . . . . . . . . . . . 723

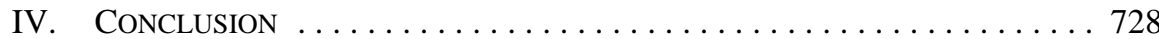

\section{INTRODUCTION}

The two murder trials of Katrina Effert have evoked strong reactions from members of the public. Some people believe that the two Alberta juries who convicted Effert of second degree murder in relation to the death of her newborn son were justified in doing so. ${ }^{1}$ Others feel that jurors should have been more compassionate to the 19-year-old young woman who kept her pregnancy a secret, gave birth to a child in the middle of the night in her parents' basement, and, hours later, strangled the infant with her underwear and tossed the body over a neighbour's fence. ${ }^{2}$ Many individuals assert that Effert should not have been convicted of second degree murder, but that she should have been found guilty of the lesser but included offence of infanticide. ${ }^{3}$ To some extent, the passionate debate about the proper fate of Katrina Effert is a reflection of the controversy surrounding the proper scope and interpretation of the infanticide provision and whether or not the retention of the offence is justified on medical and legal grounds.

In this article, it is argued that, to properly construe the elements of the infanticide offence, one must resort to the legislative history of the provision. Surprisingly, this legislative history reveals that lawmakers were prompted to enact the infanticide provision out of their dissatisfaction with what was perceived to be inappropriate outcomes of much homicide litigation directed at new mothers. Thus, despite the wording of the infanticide provision, which suggests that medical science had established a connection between childbirth and/or lactation and mental disturbances in new mothers, it was developments in the law courts, and not medical laboratories or clinics, that served as the principal catalyst for legislative reform. Unfortunately, a review of case law demonstrates that judges have not always borne legislative history in mind when interpreting the infanticide provision. This judicial oversight has led, in part, to significant uncertainty pertaining to the elements of the infanticide offence. In the first part of this article, the lack of clarity concerning the elements of infanticide is addressed and suggestions are made about the proper interpretation of the offence by resorting to a number of means, including the legislative history of the provision.

1 R. v. Effert, 2007 ABCA 284, [2007] A.J. No. 1003 (QL). Effert's first murder conviction was overturned on appeal after the Crown conceded that there were "evident concerns about whether the jury could have properly understood the issue of mens rea as it relates to the crime of infanticide, the use of expert evidence" (at para. 1).

2 For more information about the facts of this case, see Karen Kleiss, "Second Jury Convicts Baby Killer; Defence Asks Judge Not to Record Verdict” Edmonton Journal (21 June 2009) A1. For a discussion of the public reaction to the verdicts in the Effert trials, see David Staples, “The worst murder of all” The Canadian Journalism Project (15 July 2007), online: The Canadian Journalism Project <http://www.jsource.ca/english_new/ detail.php?id=1409>; "Judicial system too grey when ruling on infanticide" Wetaskiwin Times (20 August 2009), online: Wetaskiwin Times <http://www.wetaskiwintimes.com/ ArticleDisplay.aspx?e=1705199>.

3 R. v. Effert, 2009 ABCA 267, 460 A.R. 302 at paras. 1, 3-4. Effert recently applied for bail pending appeal from her most recent conviction for second degree murder. In granting Effert bail pending her appeal, Ritter J.A. noted that one of her grounds of appeal is that the jury's verdict was unreasonable and that she should only be convicted of infanticide rather than second degree murder. Infanticide is explicitly defined as an included offence to murder by the Criminal Code, R.S.C. 1985, c. C-46, s. 662(3). 
While it is hoped that the first part of this article will provide persuasive arguments that will assist those who need to properly construe the infanticide section, the second part of the article seeks to assess whether an infanticide offence should be retained as part of Canadian homicide law. Despite the fact that there is substantial evidence that many new mothers fall ill to psychiatric disorders within the first year of the birth of a child, the empirical foundation for the current infanticide provision is weak as there is little proof that childbirth or lactation per se cause mental disturbances in women. It is the adjustment to child rearing rather than the biology of childbirth that seems to be principally responsible for most instances of postnatal mental illness, including many of those instances linked to infant homicides. Consequently, it is asserted that the infanticide provision is in need of reform. Reform proposals that have been made by various organizations and adopted by certain governments are evaluated. In the end, it is recommended that Canada's current infanticide provisions be repealed and replaced by a more generally applicable defence of diminished responsibility.

\title{
II. The CRIminal Code OfFEnCE/DEFENCE OF INFANTICIDE
}

\section{A. Elements OF THE ACtUS REUS OF THE OFFENCE}

The infanticide offence is unique in two notable respects. First, it is one of two crimes within the Criminal Code that can only be committed by women. ${ }^{4}$ Second, although the Crown can charge a woman with the offence of infanticide, from a practical perspective it is often utilized as a defence by counsel for accused charged with murder in relation to their newborns. Consequently, it may be more apt to refer to the infanticide provision as giving rise to the infanticide offence/defence.

Although there is a key infanticide provision, a number of other sections of the Criminal Code play vital roles in deciphering the meaning of the provision. The infanticide section is s. 233 of the Criminal Code, which provides as follows:

\begin{abstract}
A female person commits infanticide when by a wilful act or omission she causes the death of her newly-born child, if at the time of the act or omission she is not fully recovered from the effects of giving birth to the child and by reason thereof or of the effect of lactation consequent on the birth of the child her mind is then disturbed.
\end{abstract}

Section 222(4) of the Criminal Code recognizes three forms of culpable homicide: murder, manslaughter, and infanticide. ${ }^{5}$ By virtue of ss. 222(1) and 222(5), all three forms of culpable

4 The other gender-specific offence is neglecting to obtain assistance in childbirth. The Criminal Code, ibid., s. 242 states that

[a] female person who, being pregnant and about to be delivered, with intent that the child shall not live or with intent to conceal the birth of the child, fails to make provision for reasonable assistance in respect of her delivery is, if the child is permanently injured as a result thereof or dies immediately before, during or in a short time after birth, as a result thereof, guilty of an indictable offence and is liable to imprisonment for a term not exceeding five years.

5 Ibid., s. 222(4). The maximum term of imprisonment for an accused who is convicted of infanticide is five years (s. 237), as opposed to a minimum term of imprisonment of life for murder (s. 235) and a maximum term of imprisonment of life for manslaughter (s. 236). It should be noted that an individual convicted of manslaughter is liable to a minimum punishment of imprisonment for four years where a firearm is used in the commission of the offence (s. 236). For the parole ineligibility periods for those offenders convicted of murder, see s. 745 of the Criminal Code. 
homicide involve the causing of death to a human being by means of an unlawful act or by criminal negligence. ${ }^{6}$ Section 223(1) states that "[a] child becomes a human being when it has completely proceeded, in a living state, from the body of its mother whether or not (a) it has breathed; (b) it has an independent circulation; or (c) the navel string is severed."” Consequently, before a new mother can be successfully convicted under the infanticide provision, the Crown must establish a live birth. ${ }^{8}$ The phrase "newly-born child" is defined in s. 2 of the Criminal Code as "a person under the age of one year." ${ }^{9}$ Finally and somewhat paradoxically, s. 663 provides as follows:

Where a female person is charged with infanticide and the evidence establishes that she caused the death of her child but does not establish that, at the time of the act or omission by which she caused the death of the child,

(a) she was not fully recovered from the effects of giving birth to the child or from the effect of lactation consequent on the birth of the child, and

(b) the balance of her mind was, at that time, disturbed by reason of the effect of giving birth to the child or of the effect of lactation consequent on the birth of the child,

she may be convicted unless the evidence establishes that the act or omission was not wilful.

The recently completed Goudge Commission Inquiry Report into pediatric forensic pathology services in Ontario highlights the difficulties that forensic pathologists often face in ascertaining whether children have died as a result of foul play or natural causes. The Goudge Commission Inquiry Report also notes that the complexities of forensic pathology evidence pose special challenges for lawyers. For more information on these factors and how they can contribute to wrongful homicide convictions, see The Honourable Stephen T. Goudge, Inquiry into Pediatric Forensic Pathology in Ontario: Report (Toronto: Queen's Printer for Ontario, 2008), online: Inquiry into Pediatric Forensic Pathology in Ontario $<$ www.goudgeinquiry.ca>.

$7 \quad$ Criminal Code, supra note 3, s. 223(1).

$8 \quad$ For a judicial discussion of this element of the offence, see R. v. Krueger, [1949] 2 D.L.R. 569 (Man. K.B.). Academics have noted that the requirement of live birth has been, and continues to be, a significant obstacle to obtaining homicide convictions against women who give birth unattended at home and who are alleged to have killed their infants within hours of their births: see e.g. Kirsten Johnson Kramar, Unwilling Mothers, Unwanted Babies: Infanticide in Canada (Vancouver: UBC Press, 2005) at 3, 9, 21, 177; Constance Backhouse, Petticoats \& Prejudice: Women and Law in Nineteenth-Century Canada (Toronto: Women’s Press, 1991) at 128-29, 371; Emma Cunliffe, “Infanticide: Legislative History and Current Questions” (2009) 55 Crim. L.Q. 94 at 110. If prosecutors cannot establish a live birth beyond a reasonable doubt they may resort to charging an accused under s. 242 of the Criminal Code. Alternatively, s. 662(4) expressly makes the offence under s. 243 of the Criminal Code an included offence to both murder and infanticide. Section 243 states: "[e]very one who in any manner disposes of the dead body of a child, with intent to conceal the fact that its mother has been delivered of it, whether the child died before, during or after birth, is guilty of an indictable offence and liable to imprisonment for a term not exceeding two years." However, it should be noted that the punishment for concealment of birth and the offence's scope were not always as they appear today. In 1623, An Act to prevent the Destroying and Murthering of Bastard Children (U.K.), 21 James I, c. 27 was passed in England and this statute punished by death the concealment of the dead body of any illegitimate infant by its mother unless the mother could make proof by one witness that the child was born dead. Although by the early nineteenth century this offence was extended to the colonies of Lower Canada, Nova Scotia, New Brunswick, Prince Edward Island, Newfoundland, and Upper Canada, in 1803 the English Parliament repealed the law, and by 1836 all the Canadian colonies followed suit: see Backhouse at 114, 123, 369-70.

When the infanticide provision was first enacted in 1948 (An Act to Amend the Criminal Code, S.C. 1948, c. 39, ss. 7-8), Parliament did not provide a definition of "newly-born child.” Parliament enacted its legislative definition of the phrase in 1955: see An Act respecting the criminal law, S.C. 1953-54, c. 51, s. 2(27). Prior to this amendment of the infanticide provision, McRuer C.J. in R. v. Marchello (1951), 100 C.C.C. 137 at 139 (Ont. H.C.) [Marchello] ruled that a 4.5-month-old infant was not newly born. In coming to this decision, McRuer C.J. cited, with approval, the decision of Rex v. O'Donoghue (1927), 20 Cr. App. R. 132, where the Court rejected a charge under the infanticide provision in force in England on the basis that the child was 35 days old and thus not "newly-born." 
At first blush, the wording of s. 663 seems completely at odds with that of s. 233. As one commentator has accurately observed, "one section of the Code defines an offence as requiring a certain element, and then another section dispenses with the need to prove that element."10

Nevertheless, s. 663 serves an important practical function. Before s. 663 was introduced into the Criminal Code, it was possible for an accused to be charged under s. 233 with the offence of infanticide and acquitted if she was able to raise a reasonable doubt that her mind was not disturbed at the time of the killing. Moreover, such an accused could not thereafter be charged with murder or manslaughter, as an accused person cannot be put in jeopardy twice for the same homicide. ${ }^{11}$ To avoid the prospect of a woman charged with infanticide escaping liability for the homicide by essentially leading evidence that she, while being of sound mind, murdered her newborn, ${ }^{12}$ Parliament enacted s. 663 of the Criminal Code. As indicated by the opening words of s. 663, the section is only applicable when an accused is charged with infanticide. Section 663 is not applicable where the accused is charged with murder and the defence of infanticide is raised to justify a finding of guilt to the lesser included offence. ${ }^{13}$

Carol-Ann Bauman, "Rethinking the Unthinkable: A Study of Child Homicides” (1997) 8C.R. (5th) 139 at 151.

$11 \quad$ Marchello, supra note 9. In fact, the accused in R. v. Jacobs (1952), 105 C.C.C. 291 (Ont. Co. Ct.) was charged with infanticide prior to the enactment of s. 663 and she was acquitted because there was a lack of evidence that the accused, at the time of the killing, had not fully recovered from the effect of having given birth to the child nor was there any evidence that her mind was then disturbed. Jacobs could not be subsequently prosecuted for murder or manslaughter in relation to her newborn because of the operation of the Criminal Code, supra note 3, ss. 610(2), 610(4), which state as follows:

(2) A conviction or an acquittal on an indictment for murder bars a subsequent indictment for the same homicide charging it as manslaughter or infanticide, and a conviction or acquittal on an indictment for manslaughter or infanticide bars a subsequent indictment for the same homicide charging it as murder.

(4) A conviction or an acquittal on an indictment for infanticide bars a subsequent indictment for the same homicide charging it as manslaughter, and a conviction or acquittal on an indictment for manslaughter bars a subsequent indictment for the same homicide charging it as infanticide. As observed by Kramar, supra note 8 at 106 :

The effect of infanticide law was that the defence's job was made simple: all that was required for an absolute acquittal was to prove that the woman was of sound mind (or that she acted rationally) when she killed her baby. And proof of rationality could be fairly easily established with the introduction of already established social and economic circumstances. Evidence of single motherhood could operate as proof of rational behaviour since unwed motherhood was viewed, by the courts in any case, as a socially undesirable circumstance for both mother and baby. The killing of the newly born baby, if viewed as intentional or wilful, could be located in a popular, and well established, social discourse that viewed rejection of unwed motherhood as morally virtuous. This could facilitate an acquittal for infanticide and thwart the authorities' attempts to secure convictions for culpable homicide.

For a discussion of how certain circumstantial evidence associated with some infant homicides may suggest that the culprits acted in a rational manner, see Rosemary Gartner \& Bill McCarthy, "Killing One's Children: Maternal Infanticide and the Dark Figure of Homicide” in Karen Heimer \& Candace Kruttschnitt, eds., Gender and Crime: Patterns of Victimization and Offending (New York: New York University Press, 2006) 91 at 102-103.

13 R. v. Lalli, [1993] B.C.J. No. 2010 at paras. 24-25 (Prov. Ct.) (QL) [Lalli]. In Lalli, the Court also held that infanticide is not a lesser and included offence to manslaughter. The context of the case was an application by defence counsel to a preliminary inquiry justice to commit the accused for trial on a charge of manslaughter alone. In the course of rendering his ruling on this application, de Villiers J. made the following interesting remarks:

Since conviction of manslaughter could result in a far more serious punishment than one of infanticide it may be asked why the accused should prefer to stand trial for the more serious crime of manslaughter, rather than for infanticide. This ploy on the part of the defence no doubt has its genesis in s. 234 of the Code:

"Culpable homicide that is not murder or infanticide is manslaughter".

That means that if the accused were to be put on trial for manslaughter only, and the evidence disclosed that she was guilty of infanticide, she would have to be acquitted of manslaughter, since 
The facts that must be proven to establish the actus reus of the offence of infanticide have been summarized by the judiciary. In the following often cited passage from Smith, Cummings J. stated as follows:

For the Crown to prove the offence of infanticide ... it must establish beyond a reasonable doubt that: (a) the accused is a female; (b) the child was born alive ... (c) the accused caused the death of her child; (d) the death of the child was caused by a wilful act or omission of the accused; (e) the child was newly born [meaning that the child was under one year of age]; (f) at the time of the act or omission the accused must not have fully recovered from the effects of giving birth to the child; and (g) by reason of giving birth to the child or of the effect of lactation consequent on the birth of the child her mind was then disturbed. ${ }^{14}$

As the passage from Smith indicates, there is no requirement of a causal connection between the wilful act or omission causing death and the disturbance of the mother's mind. ${ }^{15}$ Consequently, there seems to be an "implicit assumption that, if a woman with a disturbed mind kills her child, the disturbance is what led to the killing." ${ }^{\prime 16}$

In addition, there is judicial disagreement about the effect that s. 663 has on the manner in which evidence should be tendered by the Crown on a charge of infanticide. Justice Cummings in Smith held that the Crown is not, at least initially, relieved of its burden of attempting to prove that an accused charged with infanticide possessed a disturbed mind caused by childbirth at the time of the killing. Smith stands for the proposition that ss. 233 and 663 are to be read and applied in sequence. ${ }^{17}$ Consequently, prosecutors should present evidence that the accused's mind at the time of the killing was disturbed as a result of childbirth. Section 663 would only become operative if the Crown failed to prove the accused's mental disturbance beyond a reasonable doubt. As stated by Cummings J., "[s. 663] does not have any significance whatsoever if all the elements in [s. 233] are proven. But if all the elements are proven except those relating to a disturbed mind, then [s. 663] takes effect to prevent a female who was of sound mind when she caused the death of her child by a wilful act from going free."18 Thus, courts that follow Smith would require prosecutors, on a charge of infanticide, to tender expert medical evidence pertaining to the accused's state of mind at the time of the killing. However, in Lalli, the Court ruled that s. 663 renders expert medical evidence pertaining to the accused's state of mind at the time of the killing irrelevant on a charge of infanticide and that, therefore, the Crown need not even attempt to prove

manslaughter is culpable homicide that is not infanticide. It is not possible in law for an act of culpable homicide to be both manslaughter and infanticide. It can only be manslaughter if it is not infanticide.

It follows that a verdict of infanticide cannot be brought in on a charge of manslaughter. It can only be brought in as an alternative, if the accused is also charged with infanticide. Conversely, if the accused were charged with infanticide only, and the evidence establishes a form of culpable homicide that does not amount to infanticide, she cannot be convicted of manslaughter as an included offence (at paras. 9-10, 13).

After reviewing the evidence tendered at the preliminary inquiry hearing, de Villiers J. committed the accused to stand trial on one count of manslaughter and one count of infanticide arising from the death of her newborn daughter despite the fact that a conviction could only be entered at trial on one of these counts.

R. v. Smith (1976), 24 Nfld. \& P.E.I.R. 161 at para. 17 (Nfld. Dist. Ct.) [Smith].

See also R. v. B.(L.) (2008), 61 C.R. (6th) 179 at para. 47 (Ont. Sup. Ct. J.) [B.(L.)].

Isabel Grant, Dorothy Chunn \& Christine Boyle, The Law of Homicide, looseleaf (Scarborough: Carswell, 1994) at 4-91.

Smith, supra note 14 at para. 9.

Ibid. 
through expert evidence that the accused's balance of mind was disturbed as a result of childbirth. $^{19}$

\section{B. Resolving Ambiguities Concerning the ACtus Reus of the OfFence}

Although Lalli's reading out of components (f) and (g) from the definition of the actus reus of infanticide articulated in Smith may be warranted from the wording of s. 663, the Supreme Court of Canada has recognized that statutory interpretation cannot be founded on the wording of legislation alone. In recent years, the Court has endorsed an approach whereby "the words of an Act are to be read in their entire context and in their grammatical and ordinary sense harmoniously with the scheme of the Act, the object of the Act, and the intention of Parliament." ${ }^{20}$ This modern principle of statutory interpretation means that legislative intent is an important factor in determining the meaning of a statute. Scholars have traced the legislative history of s. 663 and have shown that the mischief that this provision was designed to remedy was the prospect of an accused, who wilfully killed her child, being acquitted of infanticide because the Crown was unable to prove that her mind was disturbed due to the effects of childbirth at the time of the homicide. ${ }^{21}$ Because this section was not intended to render irrelevant evidence that an accused facing an infanticide charge possessed a disturbed mind at the time of the killing, the Smith interpretation of the relationship between ss. 233 and 663 should be preferred over the one propounded by Lalli.

Recent cases also demonstrate that there is uncertainty pertaining to the meaning of the phrase "mind is then disturbed.” It has been reported that in the course of Katrina Effert's second murder trial, Veit J. charged the jury in the following manner: "The meaning of the word 'disturbed' is important in this case.... [I]t doesn't mean mentally ill.... It means just what ordinary people mean when they say it." ${ }^{\text {„2 }}$ The same trial judge in a previous decision referred to psychiatric evidence suggesting that even anger could disturb a person's mind, ${ }^{23}$ and she concluded that to establish infanticide, "the level of mental disturbance required has been set by Parliament at a very low threshold, certainly far below that required for an individual to be regarded as not criminally responsible [due to the defence of mental disorder]."24 Although refusing to set any particular diagnostic threshold for disturbance of the mind, ${ }^{25}$ Herold J. in B.(L.) adopted an approach to interpreting this phrase that differs significantly with that of Veit J. Justice Herold emphasized the importance of not setting the threshold for disturbance of the mind too low lest it cheapen the value that should be accorded to the life of the innocent victim. ${ }^{26}$

Parliamentary debates on the infanticide provision clearly suggest that Parliament intended the infanticide offence/defence to operate in situations where the accused had a mental illness associated with childbirth, albeit not necessarily a psychosis with its attendant break from

Lalli, supra note 13 at paras. 25-27.

Re Rizzo \& Rizzo Shoes Ltd., [1998] 1 S.C.R. 27 at para. 21, citing Elmer A. Driedger, Construction of Statutes, 2d ed. (Toronto: Butterworths, 1983) at 87.

Cunliffe, supra note 8 at 102-103.

Karen Kleiss, "Defence urges infanticide verdict - Accused baby killer's fate in hands of jury" Edmonton Journal (19 June 2009) B3.

R. v. Coombs, 2003 ABQB 818, 343 A.R. 212 at para. 85 [Coombs].

Ibid. at para. 37.

Janine Benedet, Case Comment on R. v. B.(L.), (2009) 61 C.R. (6th) 180 at 180.

B.(L.), supra note 15 at paras. 55-56. 
reality. ${ }^{27}$ Because the wording of the English Infanticide Act, $1922^{28}$ formed the basis of the 1948 amendments to the Criminal Code, which enacted the Canadian offence of infanticide, English Parliamentary debates concerning the Infanticide Act, 1922 help to illuminate the meaning of the concept of mental disturbance as it is used in s. 233 of the Criminal Code. In discussing when the threshold for mental disturbance is met, the Lord Chancellor stated as follows:

I am not prepared ... to say in the case of a normal healthy woman, who has given birth to a child and who kills that child, that the mere fact that she has gone through the ordinary physical suffering of a woman in childbirth, aggravated by such additional mental suffering as a woman who has an illegitimate child may be supposed to entertain - I am not prepared to go to the length of saying that those circumstances alone constitute a ground for introducing an exception to the ordinary basis of responsibility for criminal acts.... You must establish some exceptional derangement and disturbance. ${ }^{29}$

The Canadian Minister of Justice, Minister James Ilsley, who tabled the bill that was to give birth to the infanticide section of the Criminal Code, explained that the mental disturbance required to trigger the infanticide provision "applies to cases where there is not the degree of mental derangement amounting to [legal] insanity.... It does not go as far as the rule in Macnaughton's case." ${ }^{30}$ Minister Ilsley also indicated that he believed the infanticide section should apply to "slightly deranged" 31 new mothers who killed their newborns. While some would argue that slight derangement does not necessarily connote mental illness, it must be remembered that the dictionary definition of the word "deranged" is to be "disordered in mind; insane." 32 Thus it is contended that the Minister clearly contemplated that some significant level of mental illness had to be present before the infanticide provision became operative. Indeed the Minister's comments suggest that in order to trigger the infanticide offence/defence the accused must have suffered from a mental disorder within the meaning of s. 16 of the Criminal Code at the time of the offence, although neither of the two arms of

27 Evidence that, at the time of the commission of a criminal offence, an accused was suffering from a psychosis is often used to establish the defence of mental disorder (previously known as the defence of insanity), which in turn gives rise to the verdict of not criminally responsible on account of mental disorder. The reason that evidence of a psychosis is often vital to the defence of mental disorder is that the Criminal Code, supra note 3, s. 16(1), states that, to avail themselves of the defence, the mental disorder suffered by accused must make them "incapable of appreciating the nature and quality of an act or omission or of knowing that it was wrong." Consequently, as they are presently interpreted, both arms of the defence identify types of severe cognitive incapacity — an incapacity that is difficult to establish in the absence of a diagnosed psychosis. For a more detailed account of the requirements of the mental disorder defence, see Don Stuart, Canadian Criminal Law: A Treatise, 5th ed. (Scarborough: Thomson Carswell, 2007) at 385-430; Kent Roach, Criminal Law, 4th ed. (Toronto: Irwin Law, 2009) at 256-75; Eric Colvin \& Sanjeev Anand, Principles of Criminal Law, 3d ed. (Toronto: Thomson Carswell, 2007) at 429-67; Morris Manning \& Peter Sankoff, Manning, Mewett \& Sankoff: Criminal Law, 4th ed. (Markham: LexisNexis Canada Inc., 2009) at 411-50.

Infanticide Act, 1922 (U.K.), 12 \& 13 Geo. V, c. 18. Section 1(1) of the Act reads as follows:

Where a woman by any wilful act or omission causes the death of her newly-born child, but at the time of the act or omission she had not fully recovered from the effect of giving birth to such child, and by reason thereof the balance of her mind was then disturbed, she shall, notwithstanding that the circumstances were such that but for this Act the offence would have amounted to murder, be guilty of felony, to wit of infanticide, and may for such offence be dealt with and punished as if she had been guilty of the offence of manslaughter of such child.

U.K., H.L., Parliamentary Debates, 5th ser., vol. 50, col. 768 (25 May 1922).

House of Commons Debates (14 June 1948) at 5185 (Ilsley).

Ibid. at 5187.

The Oxford English Dictionary, 2d ed., s.v. “deranged.” On the use of dictionaries to interpret statutes, see Ruth Sullivan, Sullivan on the Construction of Statutes, 5th ed. (Markam: LexisNexis Canada, 2008) at 33-38. 
the mental disorder defence need to be satisfied. ${ }^{33}$ Thus, a trier of fact may be able to ground a finding of disturbance of the mind on the part of the accused at the time of the killing on the basis of expert psychiatric evidence that she suffered from any number of mental illnesses, such as severe mood disorders like depression or personality disorders. Of course, to come within the ambit of the infanticide provision, these disturbances of the mind must be established to have been caused by giving birth to the child or by the effect of lactation consequent on the birth of the child.

How direct must the causal connection be between the lack of recovery from childbirth or lactation and the disturbance in the mind of the new mother? As the second part of this article discusses, there is little evidence for a direct causal connection between the physical effects of childbirth or lactation and the causing of mental disturbances in women. Yet a more proximate causal connection can often be made between the poverty and isolation that some women experience as a result of childbirth and the postnatal mental illnesses that they suffer. For this reason, Isabel Grant, Dorothy Chunn, and Christine Boyle suggest that defence counsel should argue that the social stresses that accompany childbirth are implicated in the lack of recovery of some women from childbirth and that these social stresses should legitimately be considered to give rise to the disturbance of mind referred to in the infanticide section. ${ }^{34}$

Criminal Code, supra note 3, s. 2 defines "mental disorder" as "a disease of the mind.” For a discussion of this latter phrase, see Colvin \& Anand, supra note 27 at 441-56. The Republic of Ireland recently amended its infanticide provision by explicitly indicating that the section is operative if an individual was suffering from a "mental disorder" as defined in the Irish criminal law insanity section. For further discussion of this amendment, see Karen Brennan, "Beyond the Medical Model: A Rationale for Infanticide Legislation” (2007) 58 Northern Ireland Legal Quarterly 505 at 512.

34 Grant, Chunn \& Boyle, supra note 16 at 4-90. Professor Cunliffe argues that the wording of s. 233 makes

the precise nature of the connection [between the act of giving birth and postpartum mental illnesses] ... irrelevant... . The phrase "as a result" in combination with "the effects of giving birth ... or lactation” may encompass a range of types of causes - biological, social or environmental - or a combination of those causes, provided that they result from giving birth or from lactation. Elsewhere in Part VIII of the Criminal Code, "results" is used in a manner that connotes a temporal and proximate rather than physically causal relationship.

(Cunliffe, supra note 8 at 112 [footnotes omitted].) In R. v. Guimont (1999), 141 C.C.C. (3d) 314 at 31819 (Qc. C.A.) [Guimont], the Court held that to come within the scope of the infanticide provision, it is sufficient to establish that a pre-existing mental disorder was aggravated, but not necessarily caused, by the effects of giving birth. As is the case with the Canadian infanticide provision, the wording of the infanticide section in New South Wales, Australia requires that the accused's disturbance of balance of mind be caused only by specific aspects of child-bearing, in other words lactation or insufficient recovery from parturition itself. Robyn Lansdowne examined psychiatric assessments in all the cases where women went to trial for murdering their newborn children between 1976 and 1980 in New South Wales. In a majority of cases, the women were allowed to plead guilty to infanticide by way of negotiation on the basis of exchanged psychiatric reports. In making the connection between birth and the mother's disturbed balance of mind, Lansdowne states:

Nor is the mainstream view in psychiatric circles that psychosis after childbirth is no different to psychosis at other times, which makes it difficult to speak of the mental disorder being caused by the birth, a hindrance to the operation of the section.

[T] he psychiatrists usually relied on no more than the mere temporal sequence: birth followed by illness. They did not seek to specifically establish a causal relationship by any of the means adopted in the literature, such as ... examination for hormonal imbalance.... Most of the psychiatrists made no attempt to relate the mental disturbance explicitly to the aspects of childbearing listed specifically in the section. Nor did the prosecutor or judge require that this precise connection be drawn provided the general description "post natal" or "puerperal" was applied to the mental disturbance.

(Robyn Lansdowne, “Infanticide: Psychiatrists in the Plea Bargaining Process” (1990) 16 Monash U.L. Rev. 41 at 53 [footnotes omitted].) 
The legislative history of the infanticide provision in England does not preclude Grant, Chunn, and Boyle's interpretation of s. 233. Indeed, it seems that lawmakers in that country were aware of the social precursors to infanticide. The legislative debates surrounding the Infanticide Act, 1922 demonstrate that English Parliamentarians were cognizant that jurors were reluctant to convict women of murdering their infants. ${ }^{35}$ The death penalty associated with this crime was thought to be too harsh given the predicament faced by the typical infanticide offender, who was a young, ${ }^{36}$ unmarried domestic servant facing the prospect of giving birth to an illegitimate child, whose birth would lead to the termination of the woman's employment and severely diminished future job prospects. ${ }^{37}$ Even in those rare circumstances when a jury would convict a young mother of murdering her infant, English judges bemoaned the practice of having to don the black-cap and pass a sentence of death on the woman even though the sentence would invariably be reprieved because of the pity felt for these offenders by politicians who were well aware of the social circumstances in which these crimes were committed. One academic commentator who has reviewed the Parliamentary debates pertaining to the Infanticide Act, 1922 has concluded that the decisive factor in the enactment of an English infanticide offence was the "judicial sentiment against the 'solemn mockery'”, of passing a death sentence that was never going to be carried out. ${ }^{38}$

While there is evidence that the biological basis of the English infanticide provision may have been premised on popular perceptions about postpartum mental disturbances, ${ }^{39}$ the biological rationale for an infanticide offence does not appear to have been scientifically established. Nevertheless, an explicit socio-economic rationale for reducing the culpability of women who kill their infant children would invariably lead to calls to recognize the reduced culpability of other socially disadvantaged offenders who commit homicide. Thus, despite the fact that biological explanations for postnatal mental disturbances were not widely accepted in scientific circles, the biological basis was the least contentious way of treating murdering mothers leniently.

Although it is true that the Canadian infanticide provision was enacted 26 years after the English offence, Canadian legislators also largely ignored the scientific knowledge base concerning postpartum mental illness and merely adopted a slightly modified version of the

For a discussion of these debates, see Brennan, supra note 33 at 522.

This pattern of young mothers killing their newborn infants persists even into modern times. After examining homicide data in Canada from the period 1974-1983 involving infants under one year of age, Martin Daly and Margo Wilson concluded that the risk of maternal infanticide is a declining function of maternal age, with the risk posed to an infant being greatest in the case of a teenage mother: see Martin Daly \& Margo Wilson, Homicide (New York: Aldine De Gruyter, 1988) at 62. It is also interesting to note the prevalence of infant homicides today. Since 1974, among all child victims of homicide, which includes all victims less than 18 years of age, infants (less than a year old) are the Canadian demographic group at the highest risk of homicide: see Mia Dauvergne \& Geoffrey Li, "Homicide in Canada, 2005" (2006) 26:6 Juristat 1 at 18.

Brennan, supra note 33 at 521. Many domestic servants depended on evidence of their good character in order to maintain employment. Evidence that a domestic servant gave birth to an illegitimate child was thought to reveal that the servant lacked proper respectability.

D. Seaborne Davies, “Child-Killing in English Law” in L. Radzinowicz \& J.W.C. Turner, eds., The Modern Approach to Criminal Law, 2d ed. (London: Macmillan, 1948) 301 at 340.

See e.g. the following testimony of Sir James Fitzjames Stephen to the Royal Commission on Capital Punishment of 1864-66: "[W]omen in that [postpartum] condition do get the strongest symptoms of what amounts almost to temporary madness, and ... often hardly know what they are about, and will do things which they have no settled or deliberate intention whatever of doing," cited in Nigel Walker, Crime and Insanity in England: Volume One: The Historical Perspective (Edinburgh: Edinburgh University Press, 1968) at 128. 
text of the English Infanticide Act, $1922 .{ }^{40}$ The Parliamentary debates on Canada's infanticide provision reveal that the federal government was aware that jurors routinely refused to convict women of the capital crime of murdering their infants and instead convicted them of the crime of concealment of birth. Ottawa perceived these developments in the law courts as an inappropriate response to child homicide. Consequently, lawmakers proposed a new crime of child homicide, the infanticide offence, whose lesser penalties were aimed at addressing juror reluctance to convict these women of homicide. In explaining the need for Parliament to enact a criminal offence of infanticide, the then Minister of Justice stated:

\begin{abstract}
My information is that there are cases where the mother kills her newborn child, and that in the normal case of that kind it is useless to lay a charge of murder against the woman, because invariably juries will not bring in a verdict of guilty. They have sympathy with the mother because of the situation in which she has found herself. Therefore crown prosecutors, and those who lay charges, if they are to obtain convictions lay charges of concealment of birth; or a charge that is equal to concealment of birth. Anyone who looks at the section will see that it is really not concealment of birth, but rather concealment of the body. However, this charge is known as concealment of birth. Sentences of a few months, or even shorter than that, are imposed. To a minor extent that brings the law into disrepute, because the offence is murder; that is, unless the woman is insane.
\end{abstract}

We have placed the penalty [for the new offence of infanticide] at three years. ${ }^{41}$

At the time of the enactment of the offence, there was no evidence that lawmakers or the general public were debating the scientific merits of the biological link between childbirth and lactation and postpartum mental illness. ${ }^{42}$ As noted by Kirsten Kramar, "[t]he content of the debate illustrates that infanticide law arrived in Canada not as new biomedical or psychiatric knowledge but, rather, as a mechanism for dealing with the legal problem of too few and inappropriate convictions."43 Ironically, the psychiatric knowledge base that could have informed the English legislative debates on infanticide in the 1920s and the Canadian ones in the 1940s emphasized the socio-economic and cultural precipitators of postnatal mental illnesses and their link to infant homicides. ${ }^{44}$

40

Kramar, supra note 8 at 73. The original text of the Canadian infanticide section read as follows: A woman who by wilful act or omission causes the death of her newly born child shall be deemed not to have committed murder or manslaughter if at the time of the act or omission she had not fully recovered from the effect of giving birth to such child and by reason thereof the balance of her mind was then disturbed, but shall be deemed to have committed an indictable offence, namely, infanticide.

See An Act to Amend the Criminal Code, supra note 9, s. 7.

$41 \quad$ House of Commons Debates, supra note 30 at 5185. In 1955, the infanticide provision was amended and one of these amendments increased the maximum penalty from three to five years (An Act respecting the criminal law, supra note 9, s. 204). This increase was brought about as a result of a general restructuring of the maximum sentences within the Criminal Code, which eliminated maximum terms of imprisonment of three years. See House of Commons Debates (25 February 1954) at 2446-47. Significant historical evidence has been unearthed demonstrating that between 1840 to 1900 juries in Ontario often found women charged with murdering their newborns guilty of concealment of birth rather than murder: see Constance Backhouse, "Desperate Women and Compassionate Courts: Infanticide in Nineteenth-Century Canada” (1984) 34 U.T.L.J. 447.

$42 \quad$ Kramar, supra note 8 at 89.

$43 \quad$ Ibid. at 90.

44 For a comprehensive discussion of this psychiatric knowledge base, see ibid. at 72-96. 


\section{THE MENS REA OF THE OFFENCE}

The mens rea of the offence of infanticide is far from clear. In Smith, the Court held that the "wilful” requirement in s. 233 means that the accused must have acted with "a bad motive or purpose or with an evil intent." 45 Seventeen-year-old Smith, who did not know she was pregnant, gave birth to her child in her parents' home. When the baby began to cry, she put her hand over the child's mouth in order to avoid waking and alerting her parents. The trial judge acquitted the accused of infanticide because he had a reasonable doubt as to whether she intended to kill the child. However, in Lalli, the Court held that in order to ground a conviction under the infanticide provision, all the Crown must do is prove that the accused "ought to have realized that what she did might be harmful." 46 Two days after de Villiers J. released his decision in Lalli, the Supreme Court rendered its decision in Creighton and Canada's highest court referred, albeit it in obiter, to infanticide as the intentional killing of a child. ${ }^{47}$ Most recently, in B.(L.), the Court concluded that the mens rea required for the offence of infanticide "is more like that of murder than manslaughter."

\section{Settling the Mens Rea Debate}

Parliamentary debates surrounding the enactment of the infanticide provision suggest that the offence was intended as an alternative to finding a woman guilty of murder not manslaughter. Earlier in this article, a quote was recited from federal Minister of Justice Ilsley who, in tabling the bill enacting the infanticide provision, suggested that the need for an infanticide offence arose out of the difficulty of obtaining a murder conviction when a mother killed her newborn child. In addition, the Minister discussed the fact that some of the cases involving the killings of newborns by their mothers, which the infanticide provision was meant to address, were being dealt with by prosecutors accepting guilty pleas to manslaughter charges. He indicated that these convictions were "obtained quite improperly,

Smith, supra note 14 at para. 29.

Lalli, supra note 13 at para. 29. Arguably, this fault requirement is identical to the one required for manslaughter. In R. v. Creighton, [1993] 3 S.C.R. 3 at 20 [Creighton], the Court held that the mens rea for manslaughter consists of objective foresight of the risk of bodily harm that is more than merely trivial or transitory in nature.

Creighton, ibid. at 19. This passage was cited with evident approval by the Quebec Court of Appeal in Guimont, supra note 34 at 317.

B.(L.), supra note 15 at para. 58. The Criminal Code, supra note 3, s. 229 outlines the different fault requirements for murder. The section reads as follows:

Culpable homicide is murder

(a) where the person who causes the death of a human being

(i) means to cause his death, or

(ii) means to cause him bodily harm that he knows is likely to cause his death, and is reckless whether death ensues or not;

(b) where a person, meaning to cause death to a human being or meaning to cause him bodily harm that he knows is likely to cause his death, and being reckless whether death ensues or not, by accident or mistake causes death to another human being, notwithstanding that he does not mean to cause death or bodily harm to that human being; or

(c) where a person, for an unlawful object, does anything that he knows or ought to know is likely to cause death, and thereby causes death to a human being, notwithstanding that he desires to effect his object without causing death or bodily harm to any human being.

In R. v. Martineau, [1990] 2 S.C.R. 633 at 646, the Supreme Court ruled that a conviction for murder cannot constitutionally rest on a fault requirement less than subjective foresight of death. Consequently, the Court also stated that the phrase "ought to know" in s. 229(c) would likely not pass constitutional muster. 
because I cannot think how a charge of that kind would have any of the elements of manslaughter."49

Yet, the wording of the infanticide section, as it was originally enacted in 1948, provides fodder for those who argue that the fault element for infanticide is the same as that for manslaughter. Although it is true that Canada's infanticide offence was modelled after the English offence, the Canadian section omits the portion of the English Act that explicitly states that the infanticide provision applies in circumstances where "the offence would have amounted to murder." 50 This omission led Alan Mewett and Morris Manning to argue in the third edition of their criminal law treatise that "[i]t would appear that, in Canada, infanticide may be charged and the accused convicted thereof, if the other conditions are fulfilled when the death would otherwise have been either murder or manslaughter." ${ }^{1}$ Mewett and Manning's interpretation is bolstered by the original wording of the 1948 infanticide section, which provided that a woman would be deemed not to have committed murder or manslaughter if, at the time of the killing, her mind was disturbed as a result of non-recovery from the birthing process. The drafting of the original infanticide section certainly seems at odds with the nature of the Parliamentary debates surrounding the offence.

It is contended that the original drafters of the infanticide section simply made a drafting error. Although legislation is presumed to be accurate and well-drafted, because oversights inevitably occur courts have treated the presumption of perfection as readily rebuttable. ${ }^{52}$ Arguably, the Parliamentary debates can be used to rebut the presumption of legislative perfection. Moreover, it can be inferred that Parliament was cognizant of the drafting error because when the offence was re-enacted in 1954, the language referring to murder and manslaughter was omitted from the infanticide section. In explaining the need for the new language, the Minister of Justice said, among other things, that it was intended to deal "with the question whether an accused, under a given set of circumstances, is guilty of murder or infanticide."53

Perhaps even Manning has become convinced that the mens rea for infanticide is the same as that for murder. Although the latest edition of his criminal law treatise contains a section devoted to infanticide, there is no longer any discussion of the fault element of this offence. ${ }^{54}$

However, even if one accepts that the mens rea for manslaughter does not suffice for the offence of infanticide, the question remains: do all the forms of fault for the offence of murder suffice for the mens rea for infanticide? The obiter from Creighton ${ }^{55}$ suggests that

House of Commons Debates, supra note 30 at 5185.

Infanticide Act, 1922, supra note 28, s. 1.

Alan W. Mewett \& Morris Manning, Mewett \& Manning On Criminal Law, 3d ed. (Toronto: Butterworths, 1994) at 715 [footnotes omitted].

Sullivan, supra note 32 at 173.

House of Commons Debates (10 March 1954) at 2865.

Manning \& Sankoff, supra note 27 at 796-98. Manning and Sankoff's treatise does acknowledge that there is no practical need to extend the offence of infanticide to apply to homicides that would otherwise be manslaughter. The authors note that "[w]hile manslaughter has a much higher maximum penalty, judges have considerable leeway in sentencing for this offence, and where the facts demonstrate that the woman suffered in a manner similar to that described in [s. 233] the courts are likely to treat the manslaughter like an infanticide" (at 797, n. 320). The authors cite the following two cases to bolster their position: Coombs, supra note 23 at para. 2; R. v. Murie, [2000] O.J. No. 5029 (Sup. Ct. J.) (QL). Supra note 46. 
certain mental elements for murder, such as the one contained in s. 229(a)(ii) (whereby the offender intends to cause bodily harm that he or she knows is likely to cause death and is reckless as to whether death ensues or not), may be insufficient for the offence of infanticide. Nevertheless, there does not seem to be a plausible policy rationale for limiting the mens rea of infanticide to the intentional killing of a child. The reason that an attempt to commit a crime will often require proof of a higher form of mens rea than the crime itself is because the actus reus of an attempt offence fails to contain all of the elements of the completed offence. ${ }^{56}$ But infanticide is not an inchoate offence. The Crown must establish, just as it does for murder, that the accused caused the death of a human being in a culpable fashion. The fact that, on a charge of infanticide, the human being in question must be less than a year old and the natural offspring of the accused does not necessitate that the offence possess a more stringent form of fault than any other form of murder. Consequently, reckless killings should not be excluded from the ambit of the infanticide provision.

\section{E. THE INFANTICIDE DEFENCE}

There exists some evidence that, particularly in recent years, the preferred criminal charge laid in relation to women who are alleged to have killed their newborn infants has been murder. ${ }^{57}$ This more punitive response to homicidal mothers may be attributed, in part, to the greater number of options women are perceived to have in today's society and the greater reproductive freedom many females possess. The conditions that created a sympathetic response to young women facing unwanted children in the nineteenth and early twentieth centuries no longer exist, at least to the same extent. Giving up a baby for adoption was often not a viable alternative in the nineteenth and early twentieth centuries in Canada given the dearth of government operated programs, ${ }^{58}$ but today such programs exist and are readily accessible. Likewise, illegitimacy does not bear the stigma that it once did. Moreover, women now have greater access to safe, legal abortions as well as contraception. It may be that, increasingly, prosecuting authorities have little empathy for women who, having made the choice to have children, have underestimated the burden that child rearing would have on their lives, and seek to lift that burden by killing their infants. ${ }^{59}$

For example, in R. v. Ancio, [1984] 1 S.C.R. 225 at 248-49, the Supreme Court of Canada held that the mens rea for an attempted murder cannot be less than the specific intent to kill.

Cunliffe, supra note 8 at 108; Kramar, supra note 8 at 100, 136, 158-59, 162.

For a brief discussion of nineteenth century adoption options in Canada, see Backhouse, supra note 41 at 466 .

59 Other factors may also have, in the past, ameliorated the punitive response of the state to child homicides committed by their parents. As Judith Osborne notes:

Poverty, diseases and limited medical knowledge resulted in high rates of infant mortality. The death of newborns was a regular feature of daily life and must have helped to create an environment in which deliberate child murder seemed less reprehensible. Also, it should be noted that not only were the lives of children cheap, but also that children were viewed as the virtual property of the parent in the eyes of the law.

(Judith A. Osborne, “The Crime of Infanticide: Throwing Out the Baby with the Bathwater” (1987) 6 Can. J. Fam. L. 47 at 52 [footnotes omitted].) Even as late as 1957, Glanville Williams argued that infanticide is not as reprehensible a crime as the homicide of an adult. He stated:

Infanticide appears to our generation to be a crime less heinous than ordinary murder. Even if there is no social justification for the act, the killing of babies who are not old enough to experience fear is different from the murder of adults. This opinion was well and courageously expressed by Mercier, an English physician, in 1911.

In comparison with other cases of murder, a minimum of harm is done by it.... The victim's mind is not sufficiently developed to enable it to suffer from the contemplation of approaching suffering or death. It is incapable of feeling fear or terror. Nor is its consciousness sufficiently developed to enable it to suffer pain in appreciable degree. Its loss leaves no gap in any family circle, deprives no children of their breadwinner or their 
Consequently, infanticide is often raised as a defence by a woman charged with murdering her newborn infant. Although it is clear when a jury must be charged on the defence of infanticide, there is conflicting case law as to the burden of proof that must be satisfied before a trier of fact can return a verdict of guilt to the lesser and included offence of infanticide in a murder trial. Guimont ${ }^{60}$ establishes that where the accused is charged with murder but there is an air of reality to the contention that, at the time of the offence, the accused's mind was disturbed as a consequence of the effects of childbirth or lactation, the lesser and included offence of infanticide must be put to the jury. In B.(L.), Herold J. comes to the conclusion that before a trier of fact can return a verdict of infanticide to a charge of murder, it must be satisfied that all of the elements of the offence of infanticide are made out on a balance of probabilities. ${ }^{61}$ To hold otherwise would mean that in order for a prosecutor to obtain a conviction for murder, he or she would have to prove beyond a reasonable doubt that the accused did not suffer from a disturbed mind attributable to childbirth or lactation at the time of the killing. In B.(L.), Crown counsel argued, apparently persuasively, that the burden to prove the mental state of the accused at the relevant time was an "impossible burden of proof." 62 How this burden could be viewed as too onerous for prosecutors is puzzling. After all, in order to prove the mens rea associated with most criminal offences, prosecutors must establish the subjective mental state of the accused at the time of the offence beyond a reasonable doubt. Moreover, it has been consistently held that in order for an accused to successfully avail herself of general justifications or excuses, the only burden on the accused is the evidential one of raising a reasonable doubt as to each of the elements of the defence. ${ }^{63}$ In R. v. Effert, ${ }^{64}$ Veit J. correctly points out that requiring the Crown to prove beyond a reasonable doubt that the accused did not have a disturbed mind at the time of the killing is not an overly onerous burden because prosecutors can apply under s. 672.11(c) of the Criminal Code for an assessment of the mental condition of the accused. ${ }^{65}$ Thus, when an accused co-operates with a court ordered mental status examination, Veit J. ruled that all the accused must do to obtain a verdict of infanticide on a murder charge is to raise a reasonable doubt as to each of the elements of the infanticide defence. Strangely, however, Veit J. also suggested that where an accused invokes the defence of infanticide but refuses to co-operate with a mental status assessment, the onus of establishing the defence rests on the accused on a balance of probabilities because to hold otherwise would be to place on the Crown an "impossibly onerous burden." "66 Yet when faced with an accused who

mother, no human being of a friend, helper or companion. The crime diffuses no sense of insecurity. No one feels a whit less safe because the crime has been committed.... Its ill effect is not on society as it is, but in striking at the provision of future citizens, to take the place of those who are growing old; and by whose loss in the course of nature, the community must dwindle and die out, unless it is replenished by the birth and upbringing of children.

(Glanville Williams, The Sanctity of Life and the Criminal Law (New York: Alfred A. Knopf, 1957) at 17-18 [footnotes omitted].) Relatively low infant mortality as a result of advances in modern medicine coupled with the children's rights movements of the 1960s and 1970s as well as the increasing awareness of issues associated with child abuse have drastically altered the context in which authorities must exercise their prosecutorial discretion when dealing with child homicides.

Supra note 34.

B.(L.), supra note 15 at para. 49.

Ibid. at para. 45.

Stuart, supra note 27 at 477. It should be noted that in B.(L.), ibid. at para. 43, Herold J. states, "I agree that [the defence of infanticide] does not negate an essential element of the offence of murder but I am not entirely certain that, there being no statutory defence of infanticide, it is not a common law defence somewhat similar to justification or excuse.”

642009 ABQB 368, 244 C.C.C. (3d) 510 [Effert, Q.B.].

$65 \quad$ Ibid. at para. 20.

$66 \quad$ Ibid. at para. 24. 
refuses to co-operate with the court ordered mental status assessment, Crown counsel could and probably would simply ask the trier of fact to draw an adverse inference against the viability of the defence the accused has raised. Consequently, the extraordinary step of creating two different burdens of proof for the defence of infanticide is not warranted.

\section{THE NEED FOR LAW REFORM}

\section{A. ASSESSING THE BIOLOGICAL BASIS FOR THE INFANTICIDE OFFENCE/DEFENCE}

In the first part of this article, it was shown that the impetus for enacting an infanticide offence/defence was not the discovery of a biological link between childbirth, lactation, and maternal mental illness. Nevertheless, such a link, if it were established today, could justify the retention of an infanticide offence/defence.

There currently exists an abundance of medical literature on the topic of postpartum mood and mental disorders, and this literature tends to divide the disorders into three categories. ${ }^{67}$ The first category is known as the "baby blues." It is a mild and transitory mood disorder that affects approximately 25 to 80 percent of new mothers and it is considered to be caused by the dramatic fluctuation in hormone levels in the days after childbirth. Key symptoms of this condition include tearfulness and heightened irritability. A woman suffering from such a disorder is not considered mentally ill. The second category is more severe, and those suffering from it are considered mentally ill. Postpartum depression afflicts about 15 percent of women who have recently given birth and is often characterized by despondency, anxiety, and an inability to cope with the baby. The last category consists of women exhibiting the most extreme symptoms. Postpartum psychosis occurs in only 0.2 percent of women who give birth. Like other forms of psychosis, postpartum psychosis is marked by hallucinations and delusions.

The statements that comprise the rest of this paragraph are essentially a synopsis of the medical literature examined. This literature provides a comprehensive discussion of postnatal psychiatric disorders. The individual studies that comprise the literature consist of the following publications: R. Kumar, "Postpartum Mood Disorders: The Psychoses" in Laurence M. Demers et al., eds., Premenstrual, Postpartum, and Menopausal Mood Disorders (Baltimore: Urban \& Schwarzenberg, 1989) 163; J.A. Hamilton, "The Identity of Postpartum Psychosis" in I.F. Brockington \& R. Kumar, eds., Motherhood and Mental Illness (London: Academic Press, 1982) 41; Sarah Landy, Jacqueline Montgomery \& Susan Walsh, "Postpartum Depression: A Clinical View" (1989) 18 Maternal-Child Nursing Journal 1; M. Steiner, "Postpartum Psychiatric Disorders” (1990) 35 Canadian Journal of Psychiatry 89; Brice Pitt, “Maternity Blues” (1973) 122 British Journal of Psychiatry 431; Brice Pitt, “Atypical Depression Following Childbirth” (1968) 114 British Journal of Psychiatry 1325 [Pitt, “Atypical Depression”]; C. Dean \& R.E. Kendell, "The Symptomatology of Puerperal Illnesses” (1981) 139 British Journal of Psychiatry 128; E.S. Meltzer \& R. Kumar, "Puerperal Mental Illness, Clinical Features and Classification: A Study of 142 Mother-and-Baby Admissions” (1985) 147 British Journal of Psychiatry 647; R.E. Kendell, J.C. Chalmers \& C. Platz, “Epidemiology of Puerperal Psychoses” (1987) 150 British Journal of Psychiatry 662; P.M. Boyce \& J.M. Stubbs, “The Importance of Postnatal Depression” (1994) 161 The Medical Journal of Australia 471; Peter J. Cooper \& Lynne Murray, "Postnatal Depression” (1998) 316 British Medical Journal 1884; Katherine Wisner et al., "Postpartum Disorders: Phenomenology, Treatment Approaches, and Relationship to Infanticide” in Margaret G. Spinelli, ed., Infanticide: Psychosocial and Legal Perspectives on Mothers Who Kill (Washington, D.C.: American Psychiatric Publishing, 2003) 35 [Spinelli, Infanticide]; Margaret G. Spinelli, "Maternal Infanticide Associated with Mental Illness: Prevention and the Promise of Saved Lives” (2004) 161 American Journal of Psychiatry 1548 [Spinelli, "Maternal Infanticide”]. 
Women who kill their newborns should be, and in many cases are, treated differently by the criminal justice system depending on which category of mood or mental disorder they were suffering from at the time when they killed their children. A woman afflicted by postpartum psychosis would, in all likelihood, be able to successfully establish the defence of mental disorder because her break from reality may make her incapable of appreciating the nature and quality of her actions or knowing that her actions were wrong. Even if some forms of postpartum psychosis are not severe enough to bring an accused within the scope of the mental disorder defence, they are recognized mental disorders that would constitute a disturbance of the mind within the meaning of the infanticide provision. However, these psychoses generally are not operative on the day of delivery but present themselves 60 to 90 days after the birth of a child. ${ }^{68}$ Consequently, it would be difficult for a woman who killed her newborn within 24 hours of its birth (a neonaticide) to claim the defence of infanticide based on a disturbance of the mind caused by postpartum psychosis. Because of the prevalence of "baby blues" and its mild nature, some scholars have asserted that "[b]aby blues is probably not sufficiently exceptional to constitute a disturbance of the mind for the purposes of s. 233."69 Even if baby blues could constitute a disturbance of the mind for the purposes of s. 233, it usually takes a few days after childbirth for the hormone levels to fluctuate sufficiently to cause the mood disorder. As a result, it is also highly unlikely that an accused could rely upon baby blues to substantiate a defence of infanticide in relation to a neonaticide. Postpartum depression, like other forms of depression, is a recognized mental illness. It would therefore be sufficient to constitute a disturbance of the mind within the meaning of s. 233. However, postpartum depression typically takes weeks to develop after the birth of a child. ${ }^{70}$ Because all three types of postpartum mood and mental disorders occur sometime after the first 24 hours following birth, women accused of neonaticides do not properly fall within the scope of the infanticide provision.

But is there a basis for retaining the offence/defence of infanticide in relation to mothers who, in the days, weeks, or months after the birth, kill their newborns while suffering from a mental illness? Because the infanticide offence/defence is premised on the proposition that women may become mentally disturbed due to the direct biological effects of childbirth and lactation, it must be ascertained whether the physiological processes associated with these events cause mental illness.

Wisner et al., ibid. at 37; David Staples, “Revisiting Canada’s Infanticide Law” Edmonton Journal (12 November 2006) E6.

69 Cunliffe, supra note 8 at 111-12. But see the following comments of Veit J. in Coombs, supra note 23 at para. 85: "Although it is not necessary to make a finding on that issue in this case, it may be that even the 'baby blues' a self-rectifying condition that is not considered a mental disorder ... is a condition which 'disturbs' the mother's mind.” However, as was mentioned earlier in this article, in Coombs Veit J. maintained that the infanticide provision sets a low threshold for what constitutes a disturbance of the mind and she ruled that the provision does not require evidence of a mental disorder. Such an approach, which probably explains Veit J.'s remarks about baby blues, seems inappropriate in light of the legislative history of the infanticide section.

70 "How Could Anyone Do That?: A Therapist's Struggle With Countertransference" in Spinelli, "Maternal Infanticide," supra note 67 at 204; Pamela Meersand \& Wendy Turchin, "The Mother-Infant Relationship: From Normality to Pathology” in Spinelli, Infanticide, supra note 67, 209 at 221; Staples, supra note 68. 
There is significant evidence establishing a temporal connection between childbirth and the onset of mental disorders in women. ${ }^{71}$ For instance, a Scottish study identified all Edinburgh women with both a psychiatric contact and an episode of childbirth between 1 January 1970 and 31 December $1981 .^{72}$ Data was then collected pertaining to the psychiatric contacts of these same women during a two-year period before they became pregnant and during the two-year period after childbirth. ${ }^{73}$ The study revealed that in the first 30 days after childbirth there were nearly seven times as many psychiatric hospital admissions as the average monthly admission rate before pregnancy. ${ }^{74}$ However, this study does not establish that the biology of childbirth causes mental disorders in women. It must be remembered that many of the women in this study already had psychiatric contacts before becoming pregnant. Therefore, it may be that the physiological and/or psychological stresses associated with childbirth tend to exacerbate previously existing psychiatric conditions in new mothers. Yet, with the exception of the baby blues, there is little empirical evidence for the proposition that the changes in endocrine levels associated with childbirth cause or contribute to mood disorders or mental illnesses. ${ }^{75}$

Indeed, the general consensus emanating from medical literature ${ }^{76}$ is that the roots of postpartum mental disorders, especially postpartum depression, lie in social and psychological factors, and not in the profound biological changes that accompany childbirth. As stated by Peter Dean,

[t]he aetiological basis of postnatal depression is likely to be the same as for depression at other times and have significant psychological and social components. The change in the social circumstances, that is the presence of an infant, may make significant contribution towards psychological difficulties, as opposed to childbirth itself. For many women, there has been evidence of difficulties prior to childbirth.... Therefore, there remains little evidence that childbirth itself causes psychiatric illness. ${ }^{77}$

Some of the social and psychological factors that have been implicated in the onset of postpartum mental disorders have been noted to include poor social support, particularly poor

See T.F. Pugh et al., "Rates of Mental Disease Related to Childbearing” (1963) 268 New Eng. J. Med. 1224; R.E. Kendell et al., "The Influence of Childbirth on Psychiatric Morbidity" (1976) 6 Psychological Medicine 297; Pitt, “Atypical Depression,” supra note 67.

Kendell, Chalmers \& Platz, supra note 67 at 662-63.

Ibid. at 663 .

Ibid.

A. George \& M. Sandler, "Endocrine and Biochemical Studies in Puerperal Mental Disorders” in R. Kumar \& I.F. Brockington, eds., Motherhood and Mental Illness 2: Causes and Consequences (New York: John Wright, 1988) 78 at 104.

76 For representative samples of the medical literature concerning the aetiology of postpartum menta disorders, see E.S. Paykel et al., "Life Events and Social Support in Puerperal Depression” (1980) 136 British Journal of Psychiatry 339; G. Feggetter, P. Cooper \& D. Gath, "Non-Psychotic Psychiatric Disorders in Women One Year after Childbirth” (1981) 25 Journal of Psychosomatic Research 369; J.P. Watson et al., "Psychiatric Disorder in Pregnancy and the First Postnatal Year" (1984) 144 British Journal of Psychiatry 453; R. Kumar \& K.M. Robson, “A Prospective Study of Emotional Disorders in Childbearing Women” (1984) 144 British Journal of Psychiatry 35; M.W. O’Hara, “Social Support, Life Events, and Depression during Pregnancy and the Puerperium” (1986) 43 Archives of General Psychiatry 569; Peter J. Cooper \& Lynne Murray, “Course and Recurrence of Postnatal Depression: Evidence for the Specificity of the Diagnostic Concept” (1995) 166 British Journal of Psychiatry 191; A. Lane et al., "Postnatal Depression and Elation among Mothers and their Partners: Prevalence and Predictors” (1997) 171 British Journal of Psychiatry 550; Meir Steiner, "Postnatal Depression: A Few Simple Questions" (2002) 19 Family Practice 469; Deborah Sichel, "Neuorohormonal Aspects of Postpartum Depression and Psychosis” in Spinelli, Infanticide, supra note 67 at 61.

77 Peter John Dean, “Child Homicide and Infanticide in New Zealand” (2004) 27 International Journal of Law and Psychiatry 339 at 346. 
spousal support, ${ }^{78}$ and low socio-economic status. ${ }^{79}$ Ania Wilczynski notes the following additional factors of importance in relation to the development of postpartum depression: “[a] difficult infant temperament, the reality of motherhood bearing little relation to the idealised societal view of it, the expectations made of women to be 'perfect' mothers, and the significant social and psychological changes frequently accompanying motherhood, such as the loss of paid employment and feelings of isolation and loss of identity."

There also appears to be limited support for the proposition that the biology of lactation causes postpartum mental illness. In the United Kingdom, the Criminal Law Revision Committee received advice from the Royal College of Psychiatrists that there is little to no evidence supporting the idea that lactation causes mental disorders in new mothers. ${ }^{81}$ Consequently, the Criminal Law Revision Committee recommended that the reference to lactation be dropped from the English infanticide provision. ${ }^{82}$ Although the English infanticide provision remains unchanged, ${ }^{83}$ in Australia, the Victoria Law Reform Commission made a similar recommendation ${ }^{84}$ that led to the repeal of the Victorian infanticide provision's reference to lactation. ${ }^{85}$

In short, there exists no hard evidence that the physiological changes that accompany childbirth and lactation are implicated in causing mental disturbances in new mothers. In fact, the principal contributors to postnatal mental illness seem to be associated with the stress of child rearing rather than the biology of childbirth and/or lactation.

\section{B. LAW REFORM IMPLICATIONS}

The fact that the bulk of contemporary medical knowledge does not support a biological explanation for postpartum mental disorders does not necessarily mean that the infanticide

Cooper \& Murray, supra note 67 at 1885.

Bernadette McSherry, "The Return of the Raging Hormones Theory: Premenstrual Syndrome, Postpartum Disorders and Criminal Responsibility” (1993) 15 Sydney L. Rev. 292 at 295.

Ania Wilczynski, Child Homicide (London: Oxford University Press, 1997) at 56 [footnotes omitted]. U.K., Criminal Law Revision Committee, Offences Against the Person (14th Report, Cmnd 7844) (London: Her Majesty's Stationery Office, 1980) at 47.

Ibid.

The English Law Commission recently recommended retaining the English infanticide provision's reference to lactation on the basis of a single new study that "suggests that lactation may increase dopamine sensitivity in some women which may trigger psychoses.” The Commission stated that, "[a]lthough this evidence is not conclusive, we are not aware of evidence that definitively refutes the lactation theory.” (U.K., The Law Commission, Murder, Manslaughter and Infanticide (Project 6 of the Ninth Programme of Law Reform: Homicide, Law Com No 304) (London: The Stationery Office, 2006) at 162 [Project 6].) An infanticide bill was tabled in the English Parliament in 1936, but it failed to pass into law. As Nigel Walker has noted, the bill "would have exempted the killing of infants up to the age of eight years from the death penalty, and would have widened the definition of the mother's state of mind to include 'distress and despair arising from solicitude for her child or extreme poverty or other causes”” (Walker, supra note 39 at 132).

Australia, Victorian Law Reform Commission, Defences to Homicide: Final Report (Melbourne: Victoria Government Printer, 2004) at 265-66 [Defences to Homicide].

Crimes (Homicide) Act 2005 (Vic.), s. 5 [Crimes Act]. The New South Wales Law Reform Commission has also noted the dubious empirical foundation for lactational insanity:

[I]t seems now to be generally doubted that there is any medical basis for the notion of "lactational insanity". Inclusion of lactation as a ground of mental disturbance within the infanticide provisions appears to have been based primarily on a desire to provide a medical justification for extending infanticide beyond the first few weeks of birth.

(Austl., New South Wales Law Reform Commission, Partial Defences to Murder: Provocation and Infanticide (Report 83) (Sydney: New South Wales Law Reform Commission, 1997) at 114 [Report 83] [footnotes omitted].) 
offence/defence should be abolished. ${ }^{86}$ However, it does suggest that the current offence/defence is in need of reform.

That the social realities accompanying the birth of a child can cause mental disturbances in new mothers has been recognized by certain law reform bodies and legislatures. In the U.K., the Criminal Law Revision Committee suggested expanding the English infanticide definition to recognize that a woman's mind could be disturbed by reason of “circumstances consequent upon that birth." ${ }^{87}$ A similar recommendation made by the Victorian Law Reform Commission resulted in that Australian state adopting new infanticide provisions that are triggered, in part, by disorders consequent upon, but not necessarily caused by, childbirth. ${ }^{88}$

However, if it is the mental disturbance in new mothers that justifies their reduced culpability for the homicide of their children, the infanticide provision should include within its scope the killing of more than just the newly born child. The New Zealand infanticide provision is operative " $[\mathrm{w}]$ here a woman causes the death of any child of hers under the age of 10 years." 89 Although one may legitimately argue that the ten-year age limit is arbitrarily restrictive, it is noteworthy that, in $R . v . P .{ }^{90}$ a broad interpretation of the term, "a child of hers" was given, extending to a child under the legal guardianship of the accused and treated as part of her family. ${ }^{91}$

If the stresses of child rearing are primarily responsible for causing mental disturbances in those charged with being primary caregivers of young children, there is also no reason to limit the offence/defence of infanticide to biological mothers. Although women still tend to be the primary caregivers for children, fathers have, in ever increasing numbers, assumed this role. Even in relation to fathers who do not take the lead in providing care for their children, there may be a basis for arguing that they should be able to avail themselves of the offence/defence of infanticide. For example, Carol Smart states that should postnatal mental disturbance "be understood as a consequence of the shock of parenthood and the parents' perception of a totally changed life-style it might be feasible to argue that both parents are

86 Indeed, a proven biological link between childbirth and the causing of mental disorders in women could prove problematic for the broader cause of women's equality. It has been argued that giving women special treatment by way of an infanticide provision that is based on the notion that women are naturally susceptible to mental instability as a result of giving birth reinforces the myth that women are unstable because of their biology. This myth can and has been used as a rationale for limiting the advancement or participation of women in higher education, employment, and politics. See Grant, Chunn \& Boyle, supra note 16 at 4-100.

87 Offences Against the Person, supra note 81 at 47.

88 See Defences to Homicide, supra 84; Crimes Act, supra note 85, s. 5. Similar amendments were recently made to the Irish infanticide provision. For a comprehensive discussion of the Irish legislation and reform process, see Brennan, supra note 33 at 512, 524-28. When New Zealand first enacted an infanticide provision in 1961, the legislation included a reference to disorders consequent upon giving birth, see Crimes Act 1961 (N.Z.), 1961/43, s. 178.

89 Crimes Act 1961, ibid. The New South Wales Law Reform Commission has also recognized that restricting the scope of an infanticide provision to the killing of only newly born children leads to some illogical and arbitrary results. The Commission cites the example "of a woman who is suffering from severe depression and kills her two children, one aged less than 12 months and the other aged more than 12 months” (Report 83, supra note 85 at 119). Because of the definition of newly born child, the offence/defence of infanticide "may apply to the killing of the first child, but not to the second, despite the fact that both killings were committed in a state of significant mental disturbance" (ibid.). [1991] 2 N.Z.L.R. 116 (H.C.).

91 Ibid. at 120. In 2005, the Australian state of Victoria amended its infanticide offence/defence to cover children aged under two years: see Crimes Act, supra note 85, s. 5. 
vulnerable to psychological disturbances of this kind."92 Similarly, an argument could be raised that adoptive parents should be able to resort to the offence/defence of infanticide. ${ }^{93}$

The Law Reform Commission of Canada found much merit to these arguments. It concluded that

our current infanticide law would seem too limited in scope. As has been frequently observed, many stresses affecting a new mother may persist beyond the year following childbirth.... Certain related stresses may affect the father as well as the mother. Any of these stresses may lead to killing a child other than a new-born baby.... [M]edical evidence no longer justifies ... denying [special treatment] to fathers acting under related stresses, or to mothers who kill children over one year old.... In other words, there would be greater justification for a more general defence involving mental disturbance in such circumstances. ${ }^{94}$

The Law Reform Commission of Canada did not conceptualize this more general defence involving mental disturbance as being achieved through an expanded infanticide provision. The Commission, like many other law reform bodies that have considered this issue, ${ }^{95}$ has suggested that the infanticide offence/defence be repealed and replaced by a defence of diminished responsibility. ${ }^{96}$

Adopting such a proposal would lead to the equitable treatment of all offenders whose acts of homicide were precipitated, at least in part, by their mental illnesses. Under current Canadian criminal law, mental illness, unless it is severe enough to negate one of the essential elements of the offence, such as mens rea, ${ }^{97}$ or warrants the use of the mental disorder defence, does not prevent an accused from being subject to the full rigours of the law of murder. The one exception has been the offence of infanticide, and that exception was premised on the mental disturbance of the offender being caused by unique biological processes - childbirth and lactation. But there is little evidence that these biological

Carol Smart, Women, Crime and Criminology: A Feminist Critique (London: Routledge \& Kegan Paul, 1976) at 190, n. 2.

93 Heather Stangle recounts that

[s]ubstantial evidence has existed for some time that fathers experience significant psychological symptoms following the birth of a child. They experience, for instance, the symptoms of postpartum depression at rates similar to their female counterparts. A recent study by the American Psychological Association (APA) indicates that one in ten men meet the standards for severe postpartum depression.... Postpartum onset "exhaustion psychosis" has also been diagnosed in men with infants and young children. Exhaustion pyschosis may occur due to the stresses of parenthood and involves many of the symptoms of postpartum psychosis, including hallucinations, loss of reality, "wild rages," and even violence. Adoptive mothers have also suffered from the effects of exhaustion psychosis. Such findings suggest that the ... emotional problems associated with postpartum psychosis occur in fathers and non-biological mothers and are closely associated with the stresses and rigors of child-rearing.

(Heather Leigh Stangle, "Murderous Madonna: Femininity, Violence, and the Myth of Postpartum Mental Disorder in Cases of Maternal Infanticide and Filicide” (2008-09) 50 Wm. \& Mary L. Rev. 699 at 729-30 [footnotes omitted].) In Coombs, supra note 23 at para. 35, Veit J. states that "[ $t]$ he very restriction of the diminished responsibility benefit [of the infanticide provision] to mothers suggests a biological versus cultural component to the policy. However, would not a poor, single adoptive mother potentially be subjected to the same pressures as a biological mother?”

Law Reform Commission of Canada, Homicide (Working Paper 33) (Ottawa: Law Reform Commission of Canada, 1984) at 76 [footnotes omitted]. Majesty’s Stationery Office, 1975); Report 83, supra note 85 at 107.

$96 \quad$ Homicide, supra note 94 at 77.

$97 \quad$ See R. v. Baltzer (1974), 27 C.C.C. (2d) 118 (N.S.C.A.); R. v. Allard (1990), 57 C.C.C. (3d) 397 (Qc. C.A.); R. v. Jacquard, [1997] 1 S.C.R. 314. 
processes are the primary causes of mental illness. Social stresses are widely viewed as giving rise to postnatal mental disorders as well as other types of mental disorders. Consequently, regardless of whether an accused's homicidal actions can be significantly attributed to a postnatal mental illness or another type of mental illness, the criminal justice system's response should be the same.

Moreover, that response should be a more lenient one than would otherwise be the case. The reduced culpability of offenders whose mental illness contributed to the commission of the offence has, in the absence of a finding of continued dangerousness, been recognized by sentencing judges even in the context of homicides. ${ }^{98}$ However, the mandatory minimum life sentence for murder often prevents judges from meaningfully considering the mental illness of an offender charged with this offence.

A defence of diminished responsibility to murder, a defence that has been enacted in England, would rectify this situation and spare parents, whose social stress-induced mental illnesses contributed to the killing of their children, from the harshness of murder convictions. The scope of the defence of diminished responsibility to murder in England can be gleaned, in part, by examining the text of s. 2 of the Homicide Act, 1957:

(1) Where a person kills or is a party to the killing of another, he shall not be convicted of murder if he was suffering from such abnormality of mind (whether arising from a condition of arrested or retarded development of mind or any inherent causes or induced by disease or injury) as substantially impaired his mental responsibility for his acts and omissions in doing or being a party to the killing

(3) A person who but for this section would be liable, whether as principal or as accessory, to be convicted of murder shall be liable instead to be convicted of manslaughter. ${ }^{99}$

It has been held that the defence of diminished responsibility includes acts of irresistible impulse. ${ }^{100}$ However, in order to be considered an act of irresistible impulse, it is sufficient that the difficulty that the accused experienced in failing to control the impulse was substantially greater than would be experienced in like circumstances by an ordinary person who did not suffer from a mental abnormality. ${ }^{101}$ In other words, the impairment suffered by the accused in controlling his or her impulses need not be total, but it must be more than trivial or minimal. ${ }^{102}$ The practical necessity of advancing medical evidence in order to substantiate the defence has been recognized, ${ }^{103}$ and this medical evidence must establish that the accused was suffering from an abnormality of the mind arising from one of the causes specified in s. 2(1) of the Act. In R. v. Sanderson, the Court of Appeal of England and Wales concluded that disease or injury refers to "organic or physical injury or disease of the body

Clayton C. Ruby et al., Sentencing, 6th ed. (Markham: LexisNexis Canada, 2004) at 259. For an indepth discussion of the use of evidence of mental illness in the sentencing of criminal offenders see Ruby at 248-61.

Homicide Act, 1957 (U.K.), 5 \& 6 Eliz. II, c. 11, s. 2.

R. v. Byrne, [1960] 2 Q.B. 396 at 404 (C.A.).

R. v. Simcox, [1964] Crim. L.R. 402 (C.A.).

R. v. Lloyd, [1967] 1 Q.B. 175 (C.A.).

R. v. Dix (1981), [1982] 74 Cr. App. R. 306 at 311. 
including the brain,” and "any inherent cause” includes functional mental illness. ${ }^{104}$ The English courts have also specifically ruled that depressive illnesses, such as postpartum depression, may validly constitute the basis for the defence of diminished responsibility. ${ }^{105}$

In his recent study of infanticide convictions in England and Wales during the period 1990 to 2003, commissioned by the Law Commission of England and Wales, R.D. Mackay, Professor of Criminal Policy and Mental Health of De Monfort University, found a clear overlap between the defence of infanticide and that of diminished responsibility. ${ }^{106}$ Professor Mackay examined psychiatric reports contained in the Crown Prosecution Service files and in none of the cases that resulted in an infanticide conviction did the psychiatric reports indicate that the accused's condition would fail to give rise to the defence of diminished responsibility. ${ }^{107}$

Two aspects of the infanticide offence/defence that have been viewed by some judges and commentators as problematic would be eliminated if the Canadian Parliament repealed its infanticide provisions and enacted a defence of diminished responsibility modelled on the English defence. First, some judges have expressed concern that, in a murder trial, the burden of proof on the Crown to disprove a claim of infanticide beyond a reasonable doubt is too onerous. ${ }^{108}$ However, in relation to the English statutory defence of diminished responsibility, the burden of proof is on the accused on a balance of probabilities. ${ }^{109}$ Second, the current infanticide provision does not require proof that a woman's disturbance of mind caused her to kill her newborn. Instead, there is an implicit and controversial assumption that if a woman kills her newborn, her mental disturbance led to the killing. But in order to avail herself of the diminished responsibility defence, an accused must prove that her mental abnormality was causally connected to the killing. ${ }^{110}$

(1993), [1994] 98 Cr. App. R. 325 at 336.

David Ormerod, Smith and Hogan Criminal Law, 12th ed. (Oxford: Oxford University Press, 2008) at 512.

Project 6, supra note 83 at 193.

Ibid. at 208, 218-19. Two psychiatric reports from the same case concluded that the accused's condition would not fall within the defence of diminished responsibility, but in that case the jury, nevertheless, convicted the accused of manslaughter. In 38.9 percent of the psychiatric reports analyzed by Mackay the defence of diminished responsibility was favoured "rather than or as an alternative plea to infanticide" (ibid. at 205). It is also important to note that in 58.1 percent of the psychiatric reports filed in relation to the infanticide convictions the authors did not mention the defence of diminished responsibility at all. In relation to this fact, Mackay observes that "one cannot be confident that in the ... reports which did not mention [diminished responsibility], the authors might not have regarded [the defendant's] condition as satisfying the section 2 criteria, had they addressed that issue” (at 206).

See e.g. B.(L.), supra note 15 at para. 45 and the comments of Veit J. in Effert, Q.B., supra note 64 at para. 24.

Homicide Act, 1957, supra note 99, s. 2(2).

Project 6, supra note 83 at 158. Retaining an infanticide offence/defence in Canada that is restricted to biological mothers but that is explicitly and solely premised on the economic and social realities of child rearing may result in a successful constitutional challenge to the legislation under Canadian Charter of Rights and Freedoms, s. 15, Part I of the Constitution Act, 1982, being Schedule B to the Canada Act 1982 (U.K.), 1982, c. 11 [Charter]. Section 15 (1) of the Charter states:

Every individual is equal before and under the law and has the right to the equal protection and equal benefit of the law without discrimination and, in particular, without discrimination based on race, national or ethnic origin, colour, religion, sex, age or mental or physical disability.

In R. v. Hess, [1990] 2 S.C.R. 906, the Court was dealing with a constitutional challenge to the statutory rape provisions that made it criminal for a man to have sex with a female under 14, but did not punish corresponding behaviour between a woman and a man under 14. In ruling that s. 15 of the Charter was not violated by these provisions, the Court stated at $928-29$ as follows:

If the impugned provision creates an offence that can, as a matter of fact, be committed by either sex but goes on to specify that it is only an offence when committed by one sex, then there may well be an infringement of s. 15(1)... But if the impugned provision creates an offence that 


\section{CONCLUSION}

There are many difficulties associated with Canada's infanticide provisions, but a large number of them can be ameliorated by analyzing the legislative history of the offence/defence. By conducting this analysis, ambiguities and conflicting judicial interpretations concerning the elements of the offence/defence can be resolved. Perhaps more importantly, an examination of the history of the infanticide sections also points to the need for, and direction of, legislative reform.

As Judith Osborne eloquently and accurately states, "the medical rationale [underpinning the infanticide provision] was never in vogue or scientifically established. It was simply more conventional, conservative and less contentious than the reasons for the courts' lenient treatment of murdering mothers." "111 it is time to legally recognize the real rationale that existed and persists for compassionately exempting from the law of murder some biological mothers who kill their children. Once the law recognizes that biological mothers who kill their children may commit these acts because of the effects of mental disorders caused by social stresses, the law must also acknowledge that all parents are susceptible to such influences. Therefore, when adoptive parents and biological fathers succumb to these pressures and kill their children, they may be as deserving of lenient treatment as biological mothers.

The basis for reforming the offence/defence of infanticide also fuels the call for exempting other offenders, whose homicidal acts are spawned, in part, from mental illnesses, from the law of murder. By enacting a defence of diminished responsibility to murder, Parliament would obviate the need for a separate infanticide offence/defence.

The infanticide provisions have been called "an interesting example of myth-making by legislation." "112 However, by scrutinizing the legislative origins, judicial interpretations, and medical knowledge pertaining to the offence/defence, an even more enduring and problematic myth may be dispelled — that Canadian law adequately addresses the culpability of offenders whose acts of homicide can, at least partially, be attributed to their mental illnesses.

involves acts which, as a matter of fact, can only be committed by one sex, then it is not obvious that s. 15(1) of the Charter is infringed.... In my view, s.15(1) does not prevent the creation of an offence which, as a matter of biological fact, can only be committed by one of the sexes because of the unique nature of the acts that are proscribed.

The Court noted that the legislation being challenged criminalized the penetration of young women under 14 years of age by men. Since only males are physically capable of penetration, the Court held the section did not discriminate against men. Because the current infanticide provision is explicitly premised on the physiological effects of childbirth and only women can give birth, the infanticide provision should not be found unconstitutional on the basis of sex discrimination. Yet, if the infanticide legislation were amended, with the biological basis of the section being replaced by a rationale premised on the social stresses associated with child rearing, a man charged with the murder of his newly born child may be able to establish that because both sexes are subject to acting on these stresses, the fact that only women receive the benefit of the infanticide offence/defence infringes his s. 15 Charter right. 